\title{
Science Stand
}

\author{
A Brazilian Activist Science \& Technology Outreach Initiative
}

\section{LUIS PAULO DE CARVALHO PIASSI ${ }^{1}$, GIULIANO REIS ${ }^{2}$, RICHARD MACLURE ${ }^{2}$, EMERSON FERREIRA GOMES ${ }^{3}$, FABIANA RODRIGUES SANTOS ${ }^{1}$, TUANY DE MENEZES OLIVEIRA ${ }^{1}$, STELLA CENTOLA PUPO ${ }^{1}$, THAIS SABOYA TEIXEIRA ${ }^{1}$, LIVIA DELGADO LEANDRO DA CRUZ ${ }^{1}$, MARINA COSTA RODRIGUES AND MARIAH BORATTO PEIXOTO DOS SANTOS ${ }^{1}$}

1 School of Arts, Science and Humanities, University of Sao Paulo, 1000 Arlindo Bettio Street, Vila Guaraciaba, Sao Paulo, Sao Paulo 03828-000, Brazil

2 Faculty of Education, University of Ottawa, 145 Jeans-Jacques-Lussier Private, Ottawa, ON K1N 6N5, Canada.

3 Federal Institute of Education, Science and Technology of Sao Paulo, 100 Zélia de Lima Rosa Street, Portal dos Pássaros, Boituva, Sao Paulo 18550-000, Brazil.

\section{Responses}

JASTE is a non-refereed, open-access, journal. We encourage reader feedback on contributions to it. Please send your comments, suggestions, etc. about this paper to either or both Luis Piassi (lppiassi@usp.br) or Giuliano Reis (greis@uottawa.ca).Thanks!

\begin{abstract}
This article presents the theoretical and methodological aspects of the activist science and technology education practices of a Brazilian outreach initiative known as Science Stand. This learn-by-doing program is designed to connect science and technology to current global socio-ecological issues - such as animal rights, gender (in)equality, and climate change - through interactive activities created and performed by university students in public spaces located in marginalized communities in the Greater São Paulo Area (Brazil). In addition, we introduce several testimonies from project volunteers that support our argument concerning the role of science activism in advocating gender equity in science, fostering hope in the possibility of socio-ecological change, and promoting the democratization of science through widespread knowledge dissemination.
\end{abstract}

Keywords: activist science; science stand; ludic science; social activism; cultural manifestations; marginalized youth.

\section{Introduction: Science in society or science for society?}

Science is an essential element of society. It is "an important aspect of the lives of all citizens if they are to make informed decisions" (Gunstone, Corrigan \& Dillon, 2007, p. 4). Nevertheless, it is not equally available to everyone. Thus, science outreach programs can help to fill this accessibility gap by taking science where it is less familiar (Laursen et al., 2007; Ecklund, James \& Lincoln, 2012). In addition to becoming relevant to the lives of the people to whom such activities are aimed, they can also be transformative for those who deliver them, be them university students or academic professionals: they demand increasing understanding of the content of the activities delivered to the public and commonly favour interpersonal relationships among team members. 
In Brazil, interest in the public dissemination of science only started after the arrival of Portuguese settlers in the $19^{\text {th }}$ century, and the subsequent advent of universities, science museums, magazines, and a scientific observatory (Dantes, 2005). Nowadays, science outreach activities abound throughout the nation and have diverse purposes, from improving school science experiences to developing the quality of preservice teacher training (Massarani \& Moreira, 2003). The place and format of these initiatives - often interactive and itinerant - may vary, from demonstrations, experiments and lectures to theater plays and videos (Ferreira et al, 2007; Silva et al., 2009).

In the present article, we discuss aspects of one outreach program in Brazil, the Science Stand, which is managed by a pool of public universities ${ }^{1}$ and seeks to integrate science and technology activism by promoting educational "practices that aim to be more ethically and politically engaged and socially and environmentally responsive" (Alsop \& Bencze, 2014, p. 2) in schools as well as poor (marginalized) communities and public spaces in the São Paulo Macrometropolitan region. This area (also known as "Macrometropole Paulista" [MMP] in Portuguese) $)^{2}$ corresponds to a radius of about $100 \mathrm{~km}$ from São Paulo city and is characterized by a population of approximately 33 million people living in intense socioeconomic inequality (Haddad, 2009). It is the largest urban cluster in the Western hemisphere.

Science Stand promotes conversations amongst undergraduate students and the general public (i.e. young children, adolescents and adults) through traveling exhibitions, experimentations with everyday materials and recreational practices (Piassi, Vieira \& Santos, 2017; Piassi, Santos, Vieira, Kimura, Vizachri \& Araujo, 2018; Santos, Singh, Cruz, Piassi \& Reis, 2019). In addition, it makes use of recreational activities (e.g. games, quizzes, movie debates, playful experiments, etc.) based on popular media that emphasize narratives of fantasy and science fiction to address social issues like gender equality, animal rights, and sustainability. It also focuses on encouraging access of low-income students to undergraduate and graduate university programs. As a result, Science Stand further creates space for science and technology activism by bringing "diverse groups together with sufficiently common but divergent educational and political commitments such that they can share and learn together as 'subjects' rather than 'objects' of educational processes" (Alsop \& Bencze, 2014, p. 8). From a more Freirean perspective, the realization of such ambitious goals in a highly unequal society such as the MMP area is a revolutionary task in and of itself.

The process of disseminating scientific knowledge to the public often occurs in anti-dialogic terms, thus promoting and reinforcing a form of science indoctrination by "cultural invasion" (Freire, 2005, p. 93). In other words, if the public communication of science is not conducted in clear terms that facilitate questions and dialogue, it can turn science into a medium of academic proselytism rather than a tool for socio-ecological activism (Kerckhoff \& Reis, 2014; Reis, Ng-A-Fook \& Glithero, 2015).

In using creative methods that use natural science knowledge to address ethical, social and political issues, SS has the potential to create room for activism to flourish. Therefore, over the years, we have gathered testimonies from those involved the project, especially undergraduate students, with the objective of determining those pedagogical practices that enhance the activist nature the activist nature of the activities developed.

\section{Science Stand: An activist science and technology outreach program}

The Science Stand project is an umbrella initiative made up of a collection of several programs, each of which is named after a female character from a popular media work, like science fiction movies or

\footnotetext{
1 University of São Paulo (USP): USP East (School of Arts, Sciences and Humanities) founded in 2005; Federal University of São Paulo (UNIFESP): Campus Guarulhos (School of Philosophy, Letters and Humanities), and Diadema Campus (Institute of Environmental, Chemical and Pharmaceutical Sciences), established both in 2007; Federal Institute of São Paulo (IFSP): Campus Boituva, founded in 2002, converted into a higher education institution in 2009.

2 Official information about the Macrometropolitan São Paulo (MMP) region can be accessed at https://www.emplasa.sp.gov.br/MMP (website in Portuguese).
} 
novels. The programs (and the workgroups within each one of them) are tailored to engage specific audiences in the settings where they take place (Table1).

TABLE 1: SCIENCE STAND PROGRAMS (SUMMARY).

\begin{tabular}{|c|c|c|c|c|}
\hline Programs & $\begin{array}{l}\text { Target } \\
\text { audience }\end{array}$ & Settings & Formats & $\begin{array}{l}\text { Lines of interest } \\
\text { (strands) and } \\
\text { workgroups }\end{array}$ \\
\hline Joaninha & $\begin{array}{l}\text { Children } \\
\text { (up to } 9 \text { years- } \\
\text { old) }\end{array}$ & $\begin{array}{l}\text { Kindergarten/ } \\
\text { elementary } \\
\text { schools }\end{array}$ & $\begin{array}{l}\text { Recreative in- } \\
\text { class } \\
\text { interventions. }\end{array}$ & \multirow{4}{*}{$\begin{array}{l}\text { - Strand I (Social } \\
\text { causes): Dian and } \\
\text { Emma. } \\
\text { - Strand II (Artistic and } \\
\text { cultural artifacts and } \\
\text { practices): Lucia, } \\
\text { Maria and Rita. } \\
\text { - Strand III (Accessible } \\
\text { hands-on science): } \\
\text { Annas and Lira. }\end{array}$} \\
\hline Alice & $\begin{array}{l}\text { Pre-teenagers } \\
(10-14 \quad \text { years- } \\
\text { old })\end{array}$ & $\begin{array}{l}\text { Junior high } \\
\text { schools }\end{array}$ & $\begin{array}{l}\text { Before and after } \\
\text { school (science } \\
\text { clubs and/ or } \\
\text { recreative } \\
\text { interventions) }\end{array}$ & \\
\hline Pris & 6-14-year-olds & $\begin{array}{l}\text { Youth centers } \\
\text { for children in } \\
\text { social } \\
\text { vulnerability }\end{array}$ & $\begin{array}{l}\text { Science projects, } \\
\text { recreative and/ } \\
\text { or artistic } \\
\text { interventions } \\
\text { and science } \\
\text { clubs. }\end{array}$ & \\
\hline Ellie & General public & $\begin{array}{l}\text { Public settings } \\
\text { (e.g. parks, } \\
\text { squares, train/ } \\
\text { bus stations) }\end{array}$ & $\begin{array}{l}\text { "Street science" } \\
\text { exhibitions with } \\
\text { low-cost } \\
\text { experiments and } \\
\text { prototypes. }\end{array}$ & \\
\hline
\end{tabular}

The programs are generally coordinated by the most experienced undergraduate students in the group. Moreover, the team leader's research interests are expected to be well aligned with the proposed activities of the group. As for the workgroups (or sub-groups) within each program, they are created mainly according to 3 different strands (or lines of interest) :

- $\quad$ Strand I: Social causes.

a. Dian: animal rights and sustainability ethics involving political reasoning about the human relationship with the environment. The name is an acronym in Portuguese for "Debates and Investigations about Animals and Nature" and it is also a reference to Dian Fossey, the North American primatologist and activist who was murdered due to her work defending gorillas in Rwanda.

b. Emma: encourage and empower the presence, inclusion and valorization of women and minorities in the science arena. It is named after the English actress and activist Emma Watson.

- $\quad$ Strand II: Artistic and cultural artifacts and practices. 
a. Lucia: deals with fiction, or the depiction and conceptualization of culture through the lens of imaginative fictional artifacts. The name is a tribute to the Brazilian writer Lucia Machado de Almeida.

b. Maria: ludic practices, related to playfulness, as toys, gaming, humor and other cultural elements of enjoyment, in the context of science. The name refers to the Mexican humorist Maria Antonieta de Las Nieves (Ramos, 2016).

c. Rita: rhythm and music culture and expression in its relations to science, including songs, dance, and related practices. The name refers to the Brazilian singer and composer Rita Lee.

- $\quad$ Strand III: Accessible hands-on science.

a. Annas: development of simple and low-cost experiments and science prototypes with familiar materials of everyday life. Refers to Anna Maria Pessoa de Carvalho, Brazilian science education researcher, and to Ann Druyan, science communicator.

b. Lira: development of robotic, electronic, and programming prototypes involving maker culture and open hardware and software platforms. The name is a reference to the Brazilian NASA aerospace engineer Jacqueline Lyra.

These strands have been modified over time in order to attract increased interest from potential volunteers in line with their academic and personal pursuits. These include eagerness to examine connections between science and cultural practices (such as literature, cinema and music) and the political dimensions of science (such as feminism, veganism, environmentalism). Several students, for example, have shown interest in the representations of women in science fiction and fantasy films, and this has led to the creation of the Emma group (part of strand I). Similarly, students interested in environmental issues or animal rights, are likely to find interest in joining the Dian group (also part of strand I). The Annas group (strand III) is an attractive option for those who are sympathetic to - or have a cultural identification with - the topics of creativity and practical experimentation in science. Groups can also be combined. For instance, the Emma-Lucia group was created to discuss gender issues in science through science fiction movies and novels. The success of these strands in engaging volunteers and the public at large has been a key reason for the existence and continuing expansion of the Science Stand project.

Next, we discuss in more detail the characteristics of each one of the programs - Joaninha, Alice, Pris and Ellie - and also present the testimonials of selected participants (university students) on the perceived impact of their participation in the programs.

\section{Science Stand: Changing Testimonials}

\section{Joaninha (Ladybug)}

This is a program created for early childhood audiences, specifically children up to six years of age from public schools in low-income communities. The name is an acronym in Portuguese for "Playing, Observing, Learning, Narrating: Investigations about Nature, Humanities and Arts," which points to the goal of developing playful activities that encourage young children to reflect on topics related to nature and culture. The following themes have been examined since the program was created in 2014: astronomy, animals, logic, and animation. The successful experiences stemming out of the Joaninha program have been published elsewhere (Araujo, Pimentel, Luhman, Piassi \& Santos, 2016; Santos \& Piassi, 2016; Reis, Silva \& Piassi, 2018; Silva, Araujo, Piassi \& Santos, 2018). 
In the context of the Joaninha program, the workgroup Dian (strand I) is of particular interest from an activist science and technology education perspective. Over the years, it generated playful activities that addressed ethical and environmental problems by using board games, miniatures, role-playing, quizzes and other playful activities. In some of the activities performed in 2018, the group presented plays and played mime games based on nature photography of the Brazilian jaguar. As a result, participants (both university students and the general public) had a chance to debate deforestation, the ethical problems associated with zoos, the socio-ecological impact of raising animals for consumption, and to address questions concerning emotions in non-human animals (Peixoto, Vizachri \& Piassi, 2018). Music and singing were also used to generate discussions about the importance of bees and how they are affected by the indiscriminate use of pesticides, a topic that is relevant globally (Reis, 2014).

As part of university students' involvement as mediators between the proposed science activities and the public, they are encouraged to start their own undergraduate research, suggest the development of new activities and participate in academic conferences. Consequently, in joining the group, they also have the opportunity to grow as researchers and concerned citizens:

[Joining the group Joaninha] promoted a real transformation in my eating and consumption habits, because it has stimulated me to want to stop eating meat or reduce its consumption and also to be mindful of products I buy, especially personal hygiene products, that do animal testing, and I started to choose other options. (Anita ${ }^{3}$, 19-year old female undergraduate student in Environmental Management)

The same participant also added that, "when I, for example, talk to my mother, it is noticeable that I am trying to encourage her (...) to think the same way I do: that animals deserve to have rights like us, that they are like us." Thus, it is possible to observe that the students' involvement with the group Dian promoted significant changes in her lifestyle as an individual consumer and member of a family (i.e. beyond school). (The family-based perspective of youth consumption is an important one and is deserving more attention [Reis, 2018]). The experiences of this the group have resulted in 3 out of the 8 current mediators becoming vegan after joining the group - one of which is now producing a documentary about the vegan lifestyle in order to promote it.

\section{Alice}

Alice is a program designed for junior high school students, aged 11 to 14 years of age (Gomes \& Piassi, 2018; Piassi \& Kimura, 2016). The name is an acronym in Portuguese for "Art and Ludic in the Investigation of Science in Schools." The female character Alice (from the book Alice in Wonderland written by Lewis Carroll in 1865) was chosen to represent this program because of her curiosity and interest in unusual phenomena. Activities that have been carried out in the context of the Alice program include literary science clubs, workshops and exhibits of accessible low-cost experiments, recreational art-science projects, prototyping (i.e. simple artifacts building) and robotics workshops, and environmental and sustainability activities. The program began in 2015 in a public school in São Paulo, with activities held one hour before regular classes, between noon and $1 \mathrm{pm}$. The enrollment in the activities is voluntary and involves students from the sixth to the ninth grade. The meetings occur once or twice a week. From 2018 onwards, the main focus of the group has been on the development of a science club for girls within the Emma group (strand I).

There are two workgroups in this program that are of particular interest for this paper. The first one is Rita (strand II), which is mainly about music and musical culture. The name is an acronym in Portuguese for "Rhythms in Technology and Art-Science Research." It is a group that works with the cultural dimension of music and other rhythmic manifestations (such as dancing, poetry reading, etc.) in their multiple connections with the sciences. Besides the incorporation of scientific elements in song lyrics, there is interest in the different approaches used by artists to manifest science, like rhythm and iconography (i.e. the use of images and symbols) (Gomes \& Piassi, 2016; Gomes \& Piassi, 2018). In this way, pop-

${ }^{3}$ The names are fictitious and inspired in Brazilian singers or actresses, and were given in alphabetic order along the text. 
music videos can be used to provoke reflections about the relationship between women and science, and rock songs from the 1960 s and 1970 s become useful resources to discuss public understanding of astronomy and space missions (Gomes, 2016). In other words, teachers and students are invited to consider the complex conceptual, epistemological and sociopolitical entanglements of science, technology, society and the environment. In informal conversations, a factor usually mentioned by students as relevant for their positive learning experience in the program is the collaboration with other volunteers. The team work developed contributed to the development of students' academic skills, allowed them to put into practice what they had learned in theory and gave them a chance to interact with children and adolescents in informal settings. Although one cannot affirm that volunteers saw themselves as militants of a social cause through their work, it is clear that music can be a powerful mobilizing element. Much work remain to be done in regards to quality and duration of the engagement in socio-ecological causes mediated by music.

The second workgroup of interest for our argument is Emma (strand I), the name being an acronym in Portuguese for "Studies on Women and Minorities in Art-Science." The goal of this group is to employ mechanisms by which films, television shows, video clips, comic books and science fiction can contribute to structuring and strengthening participants' capacities to become aware of gender issues related to science and technology. Within the Alice program, Emma is currently supporting the development of two science clubs for girls: Puellae in Scientia (elementary public school) and Lab das Minas (intended for public high school students). There, university students prepare and carry out activities (e.g. experiments, debates, games, etc.) and collect and analyze data for their own undergraduate research. Although this process is often seen as challenging by university students, once they succeed in involving the public on the proposed activities, they develop not only their self-confidence, but also a sense of ownership to what they have accomplished collectively. Below, we have some excerpts transcribed from audio testimonials collected from a mobile messenger application group of the project, during the final collective assessment in 2018.

I've been here for almost three years, right? And it was the semester that I liked the most, because I think we were really able to do the things we wanted to do from the beginning and achieve goals that we had not been able to achieve. (Beth, female, undergraduate student in the Leisure and Tourism program, 20 years old)

I got attached to this place, guys, I got attached to the girls. The girls hugged me today and I was feeling so bad like... [sobbing] ... I don't know, I got attached... This is so good, being part of something that is being build, we built this togheter, guys... (Cassia, female, undergraduate student in the Natural Sciences Teaching program, 23 years old)

Although the science clubs aim to engage teenagers in science, they end up functioning as spaces of mutual empowerment that have a great impact on the lives of all participants. University students create strong bonds with themselves and also with their audience (i.e. school-age teenagers who participate in the projects). These ties create a sense of sisterhood among girls, which strengthens them as women scientists and contribute to overcoming personal limits:

I think that the fact that we go twice a week [in the science club] has made the group come together more... I also like this proximity, even us here, we're very close now. (Dira, female, undergraduate student in the Natural Sciences Teaching program, 22 years old)

Sometimes I do not integrate myself so much, sometimes I don't talk to anyone, but nevertheless I felt a bond with them [teens who participate in the club], you know, like having times when we laugh, having moments that I... You know, I really admire the girls, and I think I admire it too because I had all this vision of each of you giving opinions about different things and such. (Elis, female undergraduate student in the Public Policies Management program, 22 years old)

Elis' initial difficulty to socially integrate with other people in the group likely impacted her perception of being suited for this type of work - both academic and scientific in nature. Eventually, her decision to continue to participate in the activities indicated her belief in being able to work in science 
field. Here, it is reasonable to assume that her change in perspective was also motivated by the bonds she developed during the time spent with other girls in the program. The sense of intimacy and mutual admiration that the work can provide to participants attests to the importance of these spaces for the construction of participants' identity as both women and scientists-to-be.

What I can say from my personal experience, I was a little unmotivated with this part, I love science popularization, I love science, only that I was unmotivated, and then when I came I thought I was going to remain in the same situation, I was not very satisfied, but I think precisely because it has a very different dynamic, because it has a discussion space, it is not something I just go there for the activity because they told me to do it and it's over', no, we would sit here and try to kind of have a bond and think about what we were doing here and that for me is very important. (Elis)

I hung out here, people, I got attached to the girls, our girls hugged me today and I felt very upset [sobbing], I do not know, I got attached. (Fernanda, female undergraduate student in the Natural Sciences Teaching program, 23 years old)

Fernanda (see last quote above) felt particularly upset for leaving the project to join another group. Her discourse suggests that her connection with the group goes beyond her interest in the activities. Once again, the value of emotional bonds emerged as a facilitator of the joint construction of knowledge. It also helped participants to engage with the activities by making sense of them, which in turn is in line with Freire's (2005) notion of liberating education. Additionally, participation in the club might have offered participants a glimpse of the social roles of science, which was a frequent discussion topic. This is another aspect of the activist science nature of the Science Stand program since not all undergraduates come from a science-related program. As a result, students could start acting more as subjects - rather than objects of the educational process, thus disrupting the discrimination that women are faced in science and that ends up discouraging them from pursuing or advancing a career in science (Carr, Helitzer, Freund, Westring, McGee, Campbell, Wood \& Villablanca, 2019; Todd \& Zvoch, 2019).

\section{Pris}

This is a program aimed at children and adolescents between ages 6 and 14 who experience social vulnerability. The name is an acronym in Portuguese to "Recreational Projects of Social Inclusion in Sciences Integrating Ludic, Literature and Arts." It is a reference to Philip K. Dick's character Priscilla "Pris" Stratton in the novel Do Androids Dream of Electric Sheep? and also in the film based on it, Ridley Scott's Blade Runner (2010). In the plot, the character Pris is one of the replicating androids that live in a vulnerable context and fights for the right to survive. The program works with young people attending a Youth Centre (YC), a non-formal educational space dedicated to the care of vulnerable children and adolescents. The YC is located in a neighborhood that faces socio-economic and environmental vulnerability due to problems related to soil contamination in the region. Given the context, several groups such as Emma, Lucia, Maria and Dian have developed activities for the YC public, mostly ludic interventions that seek to stimulate a critical reflection on subjects like gender equality, animal rights and environmental awareness (Alves, Souza, Santos \& Piassi, 2017; Cruz \& Gomes, 2019; Pupo, Gomes \& Piassi, 2017; Santos \& Piassi, 2018; Santos, Singh, Cruz, Piassi \& Reis, 2019).

Maria is an acronym in Portuguese for "Manifestations of Amusement and Recreation in Inquiring Art-Science" and is a reference to the Mexican actress and humorist María Antonieta de las Nieves. The group focuses on the study of the ludic practices related to gaming, humor, toys and other ludic artifacts and practices in the context of science (Miranda \& Piassi, 2016; Ramos, 2016).

Well, when I think about my major, which is Public Policy Management, I'm going to have to work with a lot of people, organizations, leadership position, and being in Maria... In my head it's like a smaller space that I'll have to face it when I go to the job market. So, I think that for me as a person helps me a lot until I have selfcontrol, that organization issue. (Giovana, female undergraduate student in Public Policy Management, 25 years old) 
I identify myself a lot with the ludic, which is a business that has been there since childhood, and is one thing that I believe works. The playfulness, I believe it can change and transform lives. (Helena, female undergraduate student in Public Policy Management, 21 years old)

From these short testimonials, it is possible to observe that the undergraduate students involved in the Maria group, and within the Pris program, report feeling engaged and satisfied in carrying out the activities geared towards socially vulnerable children. In addition, the experience gained was seen as relevant both professionally and academically as participants have expressed wish that the activities they developed with the youth could promote social change in the community. And what is activist science and technology without hope?

\section{Ellie}

The name is an acronym in Portuguese for "Ludic Exhibitions of Outreach Itinerant Laboratories." It is named after Eleanor Arroway from Carl Sagan's book Contact (1985) and the subsequent film of the same name directed by Robert Zemeckis (1997). The program is characterized by traveling exhibition stands, where experiments and devices built with low-cost materials are displayed and stored (Piassi, Vieira \& Santos, 2017). The main purpose of the activities is to bring science and the public closer together by familiarizing them with materials with which they are in daily contact. More importantly, these activities are designed to demystify science, the practice of which is believed to be restricted to the use of expensive materials and equipment by highly skilled specialists. Thus, the model of interventions adopted by the Ellie program is to decentralize scientific dissemination practices in urban centers without requiring major financial or architectural investments (Alves, Silva \& Piassi, 2017). The exhibitions can take place in several contexts and locations, as parks, trains stations, schools, and community events. Unlike previous programs, the Ellie activities do not have a fixed programming because they are performed to general (unspecified) audiences, including the blind. The creative aspects involved with the line Annas (strand III) are well suited for the goals of the Ellis and were highlighted by one of the participants:

I like to try to develop the experiments, I like to think of new things to bring, so I like the development part of the project. I end up enjoying this stage more than the interventions, but, the interactions in the interventions, it's fantastic, and I think that it is cool how every intervention is a box of surprises. (Ivete, Textile and Fashion female undergraduate student, 22 years old [Silva, 2018, p. 276])

Based on the quote above, one can infer that one of the preferred aspects of the work for the student is the creation of new ideas for didactic prototypes and the ways they are received by the public during interventions.

To include, is to be part. For me that's it, to be part of any reality. That even if it seems not to be, it is to show that it is for everyone with any other situation that is going on in life. (Jorge, Natural Sciences Teaching program, male student, 20 years old [Silva, 2018, p. 182]).

In the case of this second participant (Jorge), we observe that the focus is not on the apparatus nor in the reaction of the public (unlike it was the case indicated in Ivete's quote). Instead, the focus was on the accessibility of scientific knowledge to people overall that resulted from the activity. This is yet another important aspect of the activist nature of the project Science Stand: it imbues participants with a sense of social responsibility for enabling the general public to have access to various realms of science (e.g. having contact with experiments, phenomena and concepts that they have never had the opportunity to experience, besides interacting directly, in an informal and pleasant way, with university students, in a social context that excludes vast segments of the population from access to higher education). There have been a few cases, for example, of young people who have visited exhibitions in public facilities and thus learned about the public university and the opportunities for access to it, including some who actually entered university and are now volunteers in the project. 


\section{Conclusions}

As one can see, the Science Stand project encompasses several different kinds of actions that are defined by 4 programs (Joaninha, Allice, Pris and Ellie) and the groups that integrate them (Dian and Emma [strand I: social issues]; Lucia, Maria and Rita [strand II: artistic and cultural approaches]; and Annas and Lira [strand III: accessible practical science experimentation]). Altogether, they engage undergraduate students from eleven programs at the EACH/ USP, including Biotechnology, Natural Sciences, Environmental Management, Public Policy Management, Leisure and Tourism, Marketing, Information Systems, and Textiles and Fashion. Ultimately, the overall objective of the program Science Stand is to encourage activist science and technology by disseminating science knowledge for socio-ecological transformation in specific marginalized areas of Sao Paulo. With this in mind, a democratic environment was created for volunteers to work, which is respectful of the plurality of participants' academic and personal interests.

In the Science Stand, students are engaged in communicating science in schools and universities (programs Joaninha and Alice), public spaces (Ellie program) and with children and adolescents in situations of vulnerability (program Pris). The possibility of integrating different groups - Annas, Dian, Emma, Lira, Maria and Rita - enables the dissemination of science in an interdisciplinary perspective, reflecting the broad participation of students from different educational levels. In addition, the merging of two groups may result in benefits for undergraduate students' lives that go beyond their academic perspectives (e.g. changing habits and attitudes towards consumerism, animal rights and other environmental problems).

Another factor that guides the whole project is gender equality in science, which underscores how the protagonism of young girls in the communication of science can be stimulated. Hence, the extensive role of young girls in the project. In addition, cultural products such as movies and video clips and the playful approach that the Science Stand uses makes the contact with science fun, relevant and encourages critical thinking about the meaning of edutainment in education.

In a country like Brazil, where large segments of the population have little access to scientific practices in their everyday life outside of school, the Science Stand has brought about important changes in the city of São Paulo. As a result, participating students create activities autonomously, thus becoming mobilizing agents (activists) in the communities where they work or visit. This, in turn, impacts their own ways of seeing and acting in the world, leading them to question fixed gender roles in science, increasing their hope for less social inequality and inviting them to take responsibility for sharing their knowledge with others. That is, students are transformed from within in the process of attempting to transform society.

\section{References}

Alsop, S., \& Bencze, L. (2014). Activism! Toward a more radical science and technology education. In L. Bencze \& S. Alsop, Activist science and technology education (pp. 1-19). New York: Springer.

Alves, A., Silva, R., \& Piassi, L. (2017). A banca da ciência nos trilhos: uma proposta de difusão dialógica da ciência nas estações de trem de São Paulo. Tropos: Comunicação, Sociedade e Cultura, 6(2), 1-17.

Alves, K., Souza, D., Santos, W., \& Piassi, L. (2017). Educação de qualidade em ambiente extraescolar: Eu quero uma horta no CCA!. Revista de Cultura e Extensão USP, 17, 43-54.

Araujo, P., Pimentel, S., Luhmann, R., Piassi, L, \& Santos, E. (2016). Atividades investigativas da Banca da Ciência com livros infantis ilustrados: Articulando o PIBID a projetos de extensão. In E. di Pietri, V. Santos, M. Utsumi \& C. Galian. (Eds.), A cooperação universidade-escola para a formação inicial de professores: O PIBID na Universidade de São Paulo (pp. 199-218). São Paulo: Livraria da Física. 
Carr, P., Helitzer, D., Freund, K., Westring, A., McGee, R., Campbell, P., Wood, C., \& Villablanca, A. (2019). A summary report from the research partnership on women in science careers. Journal of General Internal Medicine, 34(3), 356-362.

Cruz, L., \& Gomes, E. (2019). Estrelas além do tempo. Revista de Estudos Universitários, 44(2), 211-226.

Dantes, M. (2005). As ciências na história brasileira. Ciência e Cultura, 57(1), 26-29.

Ecklund, E., James, S., \& Lincoln, A. (2012). How academic biologists and physicists view science outreach. PloS One, 7(5), e36240.

Ferreira, J., Soares, M., \& Oliveira, M. (2007). Ciência móvel: Um museu de ciências itinerante. In X Reunión de la Red de Popularización de la Ciencia y la Tecnología en América Latina y el Caribe. San José: Atas eletrônicas.

Freire, P. (2005). Pegadogy of the opressed. New York: Continuum.

Gomes, E. (2016). Astros no rock: Uma perspectiva sociocultural no uso da canção na educação em ciências [Unpublished doctoral dissertation]. University of São Paulo, São Paulo.

Gomes, E., \& Piassi, L. (2016). Stars, education and progressive rock: The use of the progressive rock songs in science education. In P. Gonin, C. Atton, S. Hill, A. Moore, \& J. Williams. (Eds.), Prog rock in Europe: Overview of a persistent musical style (pp. 183-196). Dijon/FR: Éditions Universitaires de Dijon.

Gomes, E., \& Piassi, L. (2018). Rita: Divulgação científica na escola por meio de canções do rock. Revista do EDICC, 4(4). Retrieved from http://revistas.iel.unicamp.br/index.php/edicc/article/view/5827

Gunstone, R., Corrigan, D., \& Dillon, J. (2007). Why consider values and the science curriculum? In D. Corrigan, J. Dillon, \& R. Gunstone (Eds.), The re-emergence of values in science education (pp. 1-10). Rotterdam: Sense Publishers.

Haddad, M. (2009). Examining the spatial distribution of urban indicators in Sao Paulo, Brazil: Do spatial effects matter?, In M. Sirgy, R. Phillips \& D. Rahtz. (Eds.), Community quality-of-life indicators: Best cases III (pp. 99-121). Dordrecht: Springer.

Kerckhoff, A., \& Reis, G. (2014). Responsible stewards of the earth: Narratives of youth activism in high school (science). In L. Bencze \& S. Alsop (Eds.), Activist Science \& Technology Education (pp. 465476). New York: Springer.

Laursen, S., Liston, C., Thiry, H., \& Graf, J. (2007). What good is a scientist in the classroom? Participant outcomes and program design features for a short-duration science outreach intervention in $\mathrm{K}-12$ classrooms. CBE-Life Sciences Education, 6(1), 49-64.

Massarani, L., \& Moreira, I. (2003). Divulgação científica no Rio de Janeiro: Um passeio histórico e o contexto atual. Revista Rio de Janeiro, 11, 38-69.

Miranda, E., \& Piassi, L. (2016). The Ludic in the teaching process. Paper presented at the Simpósio Internacional de Iniciação Científica e Tecnológica da USP. Brazil: São Paulo.

Peixoto, M., Vizachri, T., \& Piassi, L. (2018). Nature photography and its influences on children's conceptions about animal rights. Paper presented at the Simpósio Internacional de Iniciação Científica e Tecnológica da USP. Brazil: São Paulo.

Piassi, L., \& Kimura, R. (2016). Planeta-deserto e seres ambissexuais: O estranhamento da ficção científica na discussão de conteúdos CTS. Revista Indagatio Didactia, 8(1), 1724-1737.

Piassi, L., Santos, E., Vieira, R., Kimura, R., Vizachri, T., \& Araujo, P. (2018). A banca da ciência na comunicação crítica da ciência para o público escolar. Comunicação Pública, 13(24). Retrieved from https://journals.openedition.org/cp/2255\#quotation 
Piassi, L., Vieira, R., \& Santos, E. (2017). Science stand: Crossing borders between sciences, arts, and humanities in a decentralized science dissemination program. In M. Pietrocola \& I. Gurgel (Eds.), Crossing the border of the traditional science curriculum (pp. 73-93). Rotterdam: SensePublishers.

Pupo, S., Gomes, E., \& Piassi, L. (2017). Comunicação da ciência, videoclipes e ficção científica: Uma experiência em um centro para crianças e adolescentes. Revista Comunicação - Reflexões, Experiências, Ensino, 13(1), 23-36.

Ramos, J. (2016). O cômico e a física: O riso, a quebra de expectativa e o absurdo no ensino e na divulgação da física [Unpublished doctoral dissertation]. University of São Paulo, São Paulo.

Reis, A., da Silva, T., \& Piassi, L. (2018). “É o lobo?”: Proposta de leitura e difusão da ciência na primeira infância. Revista do EDICC, 4(4). Retrieved from http://revistas.iel.unicamp.br/index.php/edicc/article/view/5845/6346.

Reis, G. (2014). Developing a global perspective in science teacher education: The case of pollination. McGill Journal of Education, 49(2), 491-500.

Reis, G. (2018). Consuming school (science) education: A family-based perspective. In G. Reis, M. Mueller, R. Gisewhite, L. Siveres, \& R. Brito (Eds.), Sociocultural perspectives on youth etbical consumerism (pp. 201-216). New York: Springer.

Reis, G., Ng-A-Fook, N., \& Glithero, L. (2015). Provoking ecojustice: Taking citizen science and youth activism beyond the school curriculum. In M. Mueller \& D. Tippings (Eds.), Ecojustice, citizen science and youth activism (pp. 39-61). New York: Springer.

Santos, F., \& Piassi, L. (2018). A mediação participativa como experiência formativa profissional. Colloquium Humanarum, 15, 97-105.

Santos, W., \& Piassi, L. (2016). Extinction of bees and robot bees. Paper presented at the Simpósio Internacional de Iniciação Científica e Tecnológica da USP. Brazil: Sao Paulo.

Santos, W., Singh, D., Cruz, L., Piassi, L., \& Reis, G. (2019). Vertical gardens: Sustainability, youth participation, and the promotion of change in a socio-economically vulnerable community in Brazil. Education Sciences, 9(161). Retrieved from https://www.mdpi.com/2227-7102/9/3/161.

Silva, L., Soares, J., Correia, N., Shinomiya, G., \& de Oliveira Júnior, Z. (2009). Caminhão com ciência: Um projeto de divulgação científica pioneiro no sul da Babia. Paper presented at the Simpósio Nacional de Ensino de Física. Brazil: Vitoria.

Silva, R. (2018). A Banca da Ciência e a pessoa com deficiência visual: Um estudo sobre a acessibilidade atitudinal na difusão cientifica. [Unpublished master's dissertation]. Universidade de São Paulo: São Paulo.

Silva, T., Araujo, P., Piassi, L., \& Santos, E. (2018). O passeio de Rosinha: Articulando saberes sociais e biológicos na infância por meio da literatura. Revista Desenredo, 14(1). Retrieved from http://seer.upf.br/index.php/rd/article/view/7285

Todd, B., \& Zvoch, K. (2019). The effect of an informal science intervention on middle school girls' science affinities. International Journal of Science Education, 41(1),102-122. 